\title{
Expression of ICAM1 and VCAM1 serum levels in rheumatoid arthritis clinical activity. Association with genetic polymorphisms
}

\author{
Rosa Elena Navarro-Hernández ${ }^{\mathrm{a}}$, Edith Oregon-Romero ${ }^{\mathrm{a}}$, Mónica Vázquez-Del Mercado ${ }^{\mathrm{a}}$, \\ Héctor Rangel-Villalobos ${ }^{\mathrm{b}}$, Claudia Azucena Palafox-Sánchez ${ }^{\mathrm{a}}$ and José Francisco Muñoz-Valle ${ }^{\mathrm{a}, *}$ \\ ${ }^{a}$ Instituto de Investigación en Reumatología y del Sistema Músculo Esquelético, Departamento de Biología \\ Molecular y Genómica, Centro Universitario de Ciencias de la Salud, Universidad de Guadalajara \\ ${ }^{\mathrm{b}}$ Instituto de Investigación en Genética Molecular, Centro Universitario de la Ciénega, Universidad de \\ Guadalajara, Ocotlán, Jalisco, México
}

\begin{abstract}
To investigate the association of sICAM-1 and sVCAM-1 with ICAM1 721G $>$ A and VCAM1 1238G $>$ C polymorphisms and rheumatoid arthritis (RA) clinical activity, sixty RA patients and 60 healthy non-related subjects (HS) matched for age and sex were recruited. Soluble adhesion molecules were determined by ELISA technique. Rheumatoid factor (RF), C reactive protein (CRP) and the erythrocyte sedimentation rate (ESR) were measured by routine methods. Disability and clinical activity was measured with Spanish-HAQ-DI and DAS28 scores, respectively. The ICAM1 and VCAM1 polymorphism were identified using the PCR-RFLP procedure. Inter-group comparison showed increased levels of sICAM-1 and sVCAM-1 in RA patients (284 and $481 \mathrm{ng} / \mathrm{mL}$ ) versus $\mathrm{HS}$ (132 and $280 \mathrm{ng} / \mathrm{mL}$ ); in the RA group, significant correlations between sVCAM-1 and RF $(r=0.402)$, ESR $(r=0.426)$, Spanish-HAQ-DI $(r=0.276)$, and DAS28 $(r=0.342)$ were found, whereas sICAM- 1 only correlated with RF $(r=0.445)$. In RA patients, a significant association with the 721A allele of ICAM1 polymorphism $(p=$ $0.04)$, was found. In addition, the allele impact $(G / A+A / A)$ of this polymorphism was confirmed, $(p=0.038$, OR $=2.3$, C.I. 1.1-5.0). sVCAM-1 and sICAM-1 serum levels reflected the clinical status in RA, independently of the ICAMI and VCAMI polymorphism. However, the ICAMI 721A allele could be a genetic marker to RA susceptibility.
\end{abstract}

Keywords: Rheumatoid arthritis, polymorphism, soluble adhesion molecules, ICAM-1, VCAM-1

\section{Introduction}

The rheumatoid arthritis (RA) natural history involves clinical manifestations characterized by remission and recurrent activity stages with variable severity, secondary mainly to chronic inflammation of the synovial membrane [1], this tissue is an exclusive microenvironment where the perpetuation of the abnormal immune response occurs [2-4]. The most important pathological mechanism at an early stage of the

* Corresponding author: José Francisco Muñoz-Valle, PhD. Insurgentes 244-1, Colonia Lomas de Atemajac, Zapopan, Jalisco, C.P. 45178, México. Tel.: +52 33 10585309; E-mail: biologiamolecular@hotmail.com. inflammation process occurs when leukocytes firmly attach to the activated synovial endothelium, infiltrate the vessel wall, activate and release interleukin-1 (IL$1)$ and tumor necrosis factor- $\alpha$, (TNF- $\alpha$ ) which in turn stimulates the endothelial cells (EC) within the joint, increasing the expression of cell adhesion molecules (CAMs). Finally, CAMs perform and mediate continuously in the leukocyte-endothelium interaction [3-6].

Along CAMs, intercellular (ICAM-1) and vascular cell (VCAM-1) adhesion molecules belong to the cytokine inducible immunoglobulin-like (Ig-like) superfamily, and are receptor-like membrane bound proteins that bind leukocyte integrins. Macrophage- 1 antigen (Mac-1) and lymphocyte function associated antigen-1 (LFA-1) are the ligands of ICAM-1, while very late 
Table 1

ICAM1 and VCAM1 SNPs data

\begin{tabular}{llccccc}
\hline Genes & Locus & SNP & Exon & $\begin{array}{c}\text { Codon } \\
\text { substitution }\end{array}$ & $\begin{array}{c}\text { Protein } \\
\text { domain }\end{array}$ & Sequence primers pairs \\
\hline ICAM $^{*}$ & $19 \mathrm{p} 13.3-13.2$ & $721 \mathrm{G}>\mathrm{A}$ & 4 & 241 Gly $>$ Arg & Ig-like 3 & $\begin{array}{l}\text { F: 5'-CCGTGGTCTGTTCCCTGTAC-3' } \\
\text { R: 5'-GAAGGAGTCGTTGCCATAGG-3' }\end{array}$ \\
& & & & & & \\
$V C A M 1 *$ & $1 \mathrm{p} 32-31$ & $1238 \mathrm{G}>\mathrm{C}$ & 6 & $413 \mathrm{Gly}>$ Ala & Ig-like 5 & $\begin{array}{l}\text { F: 5'-GCTTTTGCTTGCGATTTG-3' } \\
\text { R: 5'-CCAGTATCTTCAATGGTAGGGATG-3' }\end{array}$ \\
\hline
\end{tabular}

*Information from references 18,33, 15 and 24. ICAM1: intercellular adhesion molecule 1; VCAM1: vascular cell adhesion molecule 1; G: guanine; A: adenine; C: citosine; T: timine; Gly: glycine ; Arg: Arginine ; Ala: alanine; Ig: Immunoglobulin domain; F: forward ; R: reverse.

antigen activation-4 is the VCAM-1 ligand [7-9]. Circulating soluble CAMs (sCAMs) result either from alternating splicing of mRNA or proteolysis of the membrane-bound protein form. Increased SCAM levels are found in patients with infection, cancer, inflammatory and autoimmune diseases, as a consequence of endothelial activation. Thus, sCAM concentration reflects the endothelial expression [10,11]. Although RA has an unknown aetiology, it is considered multifactorial in origin with a polygenic component. Genetic contribution to RA, however, is still controversial [12, 13].

Since genetic variants that affect functional domains of the molecules, the ICAMI and VCAMI genes are possible factors for diseases with an inflammatory component, as well as RA.

Human ICAMI and VCAMI genes single-base polymorphisms with amino-acid substitution at the Ig-like domain are known $[14,15]$. These domains are related with leukocyte integrin binding. In fact, other ICAMI genetic polymorphisms have already been associated with RA [16-18]. Therefore, the purpose of this study was to investigate the association of genetic variants of adhesion molecules ICAM1 $721 \mathrm{G}>\mathrm{A}$ and VCAMI $1238 \mathrm{G}>\mathrm{C}$ and their soluble-protein concentration with RA clinical activity.

\section{Subjects, materials and methods}

In a case-control study, 60 RA patients classified according to the American College of Rheumatology (ACR) criteria [19] and 60 healthy subjects (HS), matched for age and sex ethnicity were studied. RA patients were recruited at the outpatient Rheumatology Department in the Hospital Civil "Fray Antonio Alcalde" from Guadalajara, Jalisco, Mexico. The HS group was composed of healthy adult volunteers. In both study groups were excluded individuals with infection diseases, malignancy, renal and metabolic diseases such as diabetes mellitus. All individuals from both groups were non-related Mexican mestizos, according to the National Institute of Anthropology [20], i.e., an individual that was born in Mexico, with a Spanish last name, and a family history of Mexican ancestors for at least three generations. A written consent form was obtained from all participants before enrolment, fulfilling Helsinki Declaration guidelines.

Patients were evaluated and classified by two independent rheumatologists. Demographic and clinical variables included age, sex, disease evolution, history of drug use, and current therapy. Disability and disease activity was measured using the Spanish HAQDI (Spanish version of the Health Assessment Questionnaire Disability Index) and DAS28 (Disease Activity Score, 28 joints) scores [21,22]. Blood samples were obtained from antecubital venipuncture after an overnight fast. Rheumatoid factor (RF), C-reactive protein (CRP, IMMAGE ${ }^{\circledR}$ Immunochemistry Systems Beckman Coulter, Inc. Fullerton, CA), erythrocyte sedimentation rate (ESR, Wintrobe method), white blood cell count (WBC) and platelet count (PLT, Cell-dyn 3700 Abbott Diagnostics ${ }^{\text {TM }}$. Abbott Park, Illinois, USA) were determined.

Serum concentrations of sICAM-1 and sVCAM-1 were determined using a commercial enzyme-linked immunosorbent assays (ELISA, R\&D Systems Inc., Minneapolis, MN, USA). Sensitivity was $0.35 \mathrm{ng} / \mathrm{mL}$ for sICAM-1 and $0.6 \mathrm{ng} / \mathrm{mL}$ for sVCAM-1.

The genotypes were characterized using the polymerase chain reaction-restriction fragment length polymorphism (PCR-RFLP) technique. Genomic DNA was extracted according to the Miller method [23]. Primer sequences for ICAMI and VCAMI amplification are shown in Table 1 . In a $25 \mu \mathrm{L}$ final volume, PCR was carried out as described previously [15,24-26]. In brief, amplified fragments $(15 \mu \mathrm{L})$ were subjected to restriction enzyme digestion, $1 \mathrm{U}$ of Bsr GI or Cac 8I, (New England Biolabs Inc., Ipswich, MA, USA), during 2 and $16 \mathrm{~h}$ at $37^{\circ} \mathrm{C}$, for $I C A M I$ or $V C A M I$ genes, respectively. Electrophoresis was done at a constant voltage 


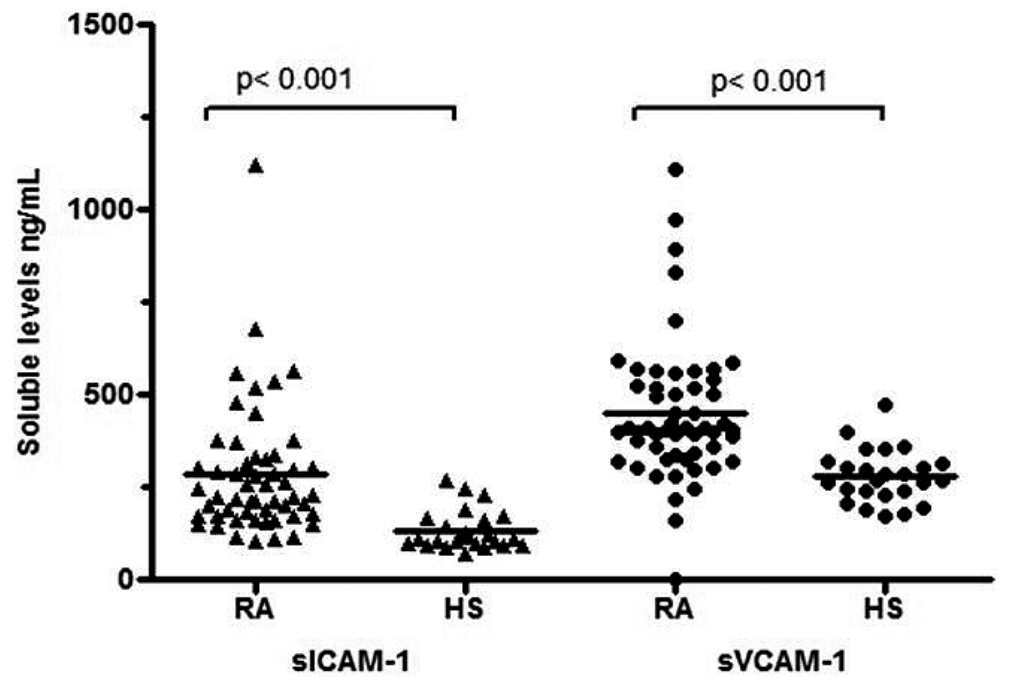

Fig. 1. Serum concentrations of sICAM-1 and sVCAM-1 in RA (rheumatoid arthritis) and HS (healthy subjects). CAM serum levels are expressed as mean $\pm \mathrm{SD}$.

of $80 \mathrm{~V}$ on $3 \%$ agarose gels stained with $0.1 \mu \mathrm{g}$ of ethidium bromide.

ICAMI allele G lacks BsrGI a restriction site and is defined by a $110 \mathrm{bp}$ fragment, while allele $\mathrm{A}$, that contains this restriction site, as two digested bands of 90-20 bp. VCAMI allele $\mathrm{G}$ (absent Cac $8 I$ restriction site) is represented by a $251 \mathrm{bp}$ fragment, and allele $\mathrm{C}$ (containing the restriction site) by two bands 201 and $50 \mathrm{bp}$ in length. On both polymorphisms the homozygote showed the corresponding single-band pattern of each allele, and heterozygote exhibit a three-band pattern. For confirmation purposes, representative samples of each genotype were sequenced in an ABIPRISM 310 Sequencer (Applied Biosystems Foster, City, CA, USA).

All data were captured and analyzed using SPSS version 10.0 (SPSS Inc. Chicago, Illinois). Arithmetic mean, minimum, and maximum values for quantitative data are presented. Mean comparison of two independent samples between groups was performed (Student $t$ test). Data from serum concentrations of CAMs, the laboratorial assessment and disease variables were subjected to Pearson and Spearman's correlation tests. Genotype inter-group comparisons by means of all variables were done with the Kruskal-Wallis and the MannWhitney U tests. An $X^{2}$ test, with Yates' correction when was applicable, was used to test genotype proportions against Hardy-Weinberg expectations. Intergroup allele comparisons were performed by the Fisher exact test. Odds ratios (ORs, with $95 \%$ confidence intervals, $\mathrm{CI}_{95}$; Epi Info 6.04, CDC) were calculated for allele and RA status. A $p<0.05$ value was considered as the statistically significant threshold.

\section{Results}

\subsection{Clinical features}

The HS mean age was $39 \pm 12$ years whereas in RA group was $46 \pm 13$ years and the ratio male/female was 9/51 in both groups. The mean body mass index was similar in HS and RA groups $\left(26 \pm 4.0 \mathrm{~kg} / \mathrm{m}^{2}\right.$ and 27 $\pm 4 \mathrm{~kg} / \mathrm{m}^{2}$, respectively). The disease mean duration was $10.7 \pm 9$ years. The extraarticular manifestations and drug treatment of the RA patients are shown in Table 2. None of the patients were treated with any TNF $\alpha$ blockers.

\subsection{Comparison of SICAM-1 and SVCAM-1 levels between RA and HS}

The RA group showed higher levels of sICAM-1 and sVCAM-1 (284 and $481 \mathrm{ng} / \mathrm{mL}$ ) than HS (132 and $280 \mathrm{ng} / \mathrm{mL}$, respectively) (Fig. 1).

\section{3. sCAM correlations}

sICAM-1 and sVCAM-1 were correlated between them $(r=0.40, p=0.002)$. Significance between sVCAM-1 and RF (53 seropositives and 7 seronegatives), ESR levels, Spanish HAQ-DI, and DAS28 was found, whereas sICAM-1 only correlated with RF. The correlations are shown in Table 3. 


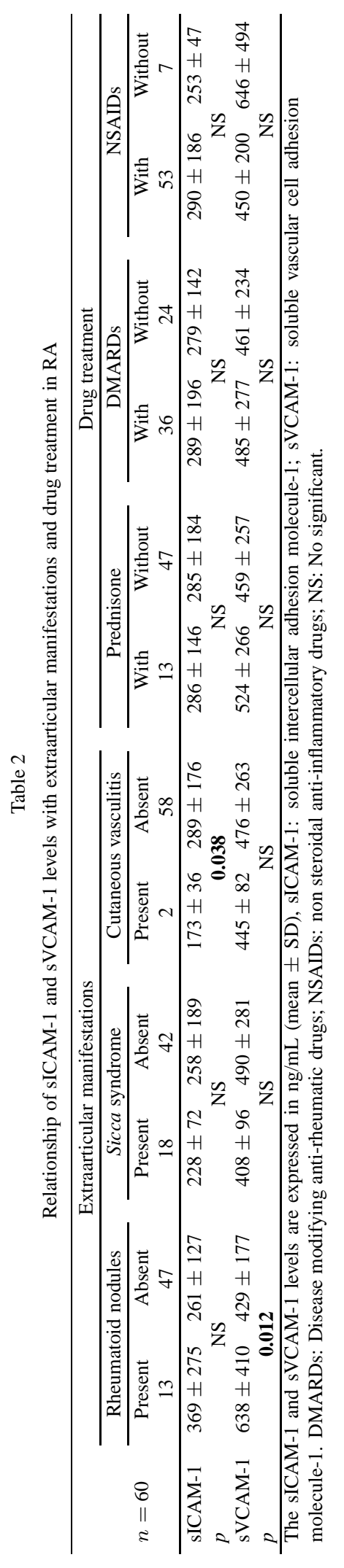


Table 3

Correlations of sICAM-1 and sVCAM-1 with the laboratorial assessments and RA activity indexes

\begin{tabular}{|c|c|c|c|c|c|}
\hline \multirow[t]{2}{*}{ Laboratorial assessment } & \multirow[t]{2}{*}{ Mean \pm SD } & \multicolumn{2}{|c|}{ sICAM-1 } & \multicolumn{2}{|c|}{ sVCAM-1 } \\
\hline & & $\mathrm{r}$ & $\mathrm{p}$ & $\mathrm{r}$ & $\mathrm{p}$ \\
\hline sICAM-1 (ng/mL) & $285 \pm 174$ & - & - & - & - \\
\hline sVCAM-1 (ng/mL) & $475 \pm 258$ & 0.404 & 0.002 & - & - \\
\hline $\mathrm{RF}(\mathrm{UI} / \mathrm{mL})$ & $607.9 \pm 1142$ & 0.445 & 0.005 & 0.402 & 0.005 \\
\hline${ }^{\#} \operatorname{ESR}(\mathrm{mm} / \mathrm{h})$ & $40.3 \pm 11$ & 0.270 & NS & 0.426 & 0.003 \\
\hline $\mathrm{CRP}(\mathrm{mg} / \mathrm{L})$ & $29.7 \pm 38$ & 0.005 & NS & 0.029 & NS \\
\hline Activity indexes & & & & & \\
\hline \#HAQ-DI (score 0-3) & $1.20 \pm 0.8$ & 0.097 & NS & 0.276 & 0.046 \\
\hline \# DAS 28 (score $0-10)$ & $6.23 \pm 1.2$ & 0.120 & NS & 0.342 & 0.048 \\
\hline
\end{tabular}

sICAM-1: soluble intercellular adhesion molecule-1; sVCAM-1: soluble vascular cell adhesion molecule-1. RF: rheumatoid factor; ESR: erythrocyte sedimentation rate; CRP: C reactive protein; HAQ-DI: Health Assessment Questionnaire Disability Index (Spanish version); DAS28: Disease Activity Score using 28 joint counts; $r$ : correlation coefficient; *Pearson correlation; ${ }^{\#}$ Spearman correlation.

Table 4

Genotype and allele frequency of ICAMI $721 G>$ A polymorphism

\begin{tabular}{ccccccrr}
\hline Group & \multicolumn{2}{c}{ Genotype, $n(\%)$} & Impact of allele $A, n(\%)$ & \multicolumn{2}{c}{ Allele, $n(\%)$} \\
\cline { 2 - 4 } \cline { 6 - 8 } & $G / G$ & $G / A$ & $A / A$ & & G/A plus $A / A$ & \multicolumn{1}{c}{$A$} & \multicolumn{1}{c}{$A$} \\
\hline$R A$ & $31(53)$ & $26(42)$ & $3(5)$ & $* 29(47)$ & $88(73)$ & $* 32(27)$ \\
$H S$ & $43(63)$ & $15(33)$ & $2(4)$ & $17(37)$ & $101(83)$ & $19(17)$ \\
\hline
\end{tabular}

RA: rheumatoid arthritis HS: Healthy subjects $n=60$ by group. Genotype inter-group comparison yielded a non-significant difference. *Allele frequency $(p=0.040)$ and impact of A allele (genotypes G/A plus A/A) $[p=0.038$; OR $=2.3$ (1.1 to 5.0)], in RA group versus $\mathrm{HS}$ group was different.

Table 5

Genotypes and allele frequency of VCAM1 $1238 \mathrm{G}>\mathrm{C}$ polymorphism

\begin{tabular}{ccccccc}
\hline \multirow{2}{*}{ Group } & \multicolumn{3}{c}{ Genotype, $n(\%)$} & & \multicolumn{2}{c}{ Allele, $n(\%)$} \\
\cline { 2 - 4 } \cline { 6 - 7 } & $G / G$ & $G / C$ & $C / C$ & & $G$ & $C$ \\
\hline$R A$ & $58(97)$ & $2(3)$ & $0(0)$ & & $118(98)$ & $2(2)$ \\
$H S$ & $59(98)$ & $1(2)$ & $0(0)$ & & $119(99)$ & $1(1)$ \\
\hline
\end{tabular}

Allele and genotype inter-group comparison (exact test) yielded nonsignificant differences.

\subsection{Genetic polymorphisms}

Genotype and allele frequencies in RA and HS are shown in Tables 4 and 5. For both polymorphisms, genotype proportions in HS group did not deviate from the ones predicted by the Hardy-Weinberg law $(p>$ $0.05)$.

ICAM1 polymorphism analysis (Table 4) showed a higher frequency of A allele in RA than HS groups (27\% vs $17 \%, p=0.04)$. The genotype analysis did not show statistical significance $(p=0.10)$. When we analyzed the allele impact, including the genotypes that containing A allele (represented by genotypes G/A plus A/A) a significant association in RA group was found $(p=0.038, \mathrm{OR}=2.3, \mathrm{CI} 1.1-5.0)$. No differences $(p>$ 0.10 ) in other variables [HAQ-DI, DAS28, RF, CRP,
ESR, WBC, and PLT] were observed. With respect to $V C A M 1$ polymorphism non significant association was found.

\section{Discussion}

In this case-control study, elevated levels of SICAM1 and sVCAM-1 reflected the clinical activity in RA. This finding is supported because we identified a significant correlation between SVCAM-1 with sICAM1, RF and ESR levels; Spanish-HAQ-DI and DAS28 indexes.

High levels of sCAMs have been observed in RA, juvenile RA, psoriatic arthritis, juvenile idiopathic arthritis, synovitis and osteoarthritis [27-32]. In our study, the correlations between sCAMs levels with the clinical activity suggest that they have a significant role in the pathogenesis of the disease. Klimiuk et al., observed high serum levels of sICAM-1 and sVCAM-1 in RA patients with synovitis, especially with follicular type of synovitis [31]. In the present study, the positive correlation between sVCAM-1 and clinical scores, RF and ESR, was observed, whereas, we only identified a positive correlation between SICAM-1 with RF. These 
findings suggest that, sVCAM-1 could play a preferential role in RA. These results are supported by previous reports that described a significant positive correlation between sVCAM-1 with ESR and CRP, meanwhile sICAM-1 did not correlate either with disease markers or clinical activity scores $[27,28,31,32]$. The possible explanation is that ICAM-1 is a molecule of constitutive expression, whereas VCAM-1 is inducible by cytokine stimulation such as TNF- $\alpha$ and IL- $1 \beta$, two abundant cytokines in inflamed RA synovium $[24,28$, 33].

In addition, when classified the RA patients according to extraarticular manifestations, we identified a significant association between the presence of rheumatoid nodules with high levels of sVCAM-1. This finding is significant because previously Corona-Sánchez et al., reported high TNF- $\alpha$ levels in RA patients with extraarticular manifestations [47]. Alternately, Elewaut et al., 1998 and Edwards et al., 1993, confirms the low or absent expression of VCAM-1 versus ICAM-1 expression that was more pronounced in the RA-nodules [48, 49]. The probable justification is that TNF- $\alpha$ induce de novo expression of VCAM-1 and upregulate ICAM1 on vascular endothelium [27]. Rheumatoid nodules are the most frequent extraarticular sign in RA, classic rheumatoid nodules commonly occur in genetically predisposed patients and correlated with severe and seropositive arthritis [50].

In contrast we did not find association between the presence of rheumatoid-vasculitis and high levels of sICAM-1. However, this finding is important because systemic rheumatoid-vasculitis frequently affects small and medium-size blood vessels, is one of the most harmful complications of RA and more often than not occurs in patients who have longstanding disease, generally of more than 10 year duration.

Other studies support the existence of histological patterns of CAMs in cutaneous necrotizing vasculitis and endothelial cells, which expressed increased levels of ICAM-1 and VCAM-1. In RA patient's formerly low frequency of clinical features of RA-associated vasculitis has been reported, on the other hand a typical predictors of vasculitis in patients with RA consist of clinical and genetic factors these to broadcast especially influence on the occurrence of the disease in the susceptible host [51-53]. Nonetheless, although rheumatoid-vasculitis is an unusual but well described complication of RA, this result cannot be completely explained because, first the RA-vasculitis pathophysiology continues to be imperfectly understood and, second we only indentified two RA patients with vasculitis.
Given their central role in the inflammatory response, suggested by other authors [15,34-36] the ICAMI and $V C A M 1$ genes are potential candidate genes for inflammatory diseases.

Here, we did not find an association between genetic variants of ICAMI $721 \mathrm{G}>\mathrm{A}$ and VCAM1 $1238 \mathrm{G}>\mathrm{C}$ polymorphism with the sICAM-1 and sVCAM-1 expression respectively (data not shown). However, an associated study in healthy subjects, reported a significant effect of ICAMI $(721 \mathrm{G}>\mathrm{A} / 241 \mathrm{Gly}>\mathrm{Arg})$ with serum sICAM-1 levels, but this was a very weak association [37].

The genetic contribution to RA susceptibility is well accepted [12,13]. The ICAM1 721G $>$ A polymorphism has been associated in several diseases including: Behcet's disease [34], endometriosis [35,36], protection from transplant associated vasculopathy after cardiac transplantation [38], Graves disease [39], polymyalgia rheumatica/giant cell arteritis [40], chronic renal allograft failure [41], whereas other studies failed to find a significant contribution of the $721 \mathrm{~A}$ allelic variant in inflammatory diseases [14,25,42-46]. In our RA group, a significant association with the $721 \mathrm{~A}$ allele variants of ICAM1 polymorphism ( $p<0.04)$, was found. However, when we analyzed the allele impact $(\mathrm{G} / \mathrm{A}+\mathrm{AA})$ of this polymorphism a significant association for the 721A allele was confirmed $(p<0.038, \mathrm{OR}=2.3$, C.I. 1.1-5.0). Our results are in agreement with the study of Macchioni et al., whom reported association with the 721A (R241) allele in Italian RA patients. Moreover, this study showed a frequency of $12.8 \%$ 721A/R241 allele in RA patients [16], whereas in the present study a $27 \%$ frequency was found. Another study of Korean RA patients this polymorphism was not identified [18]. These differences between populations can be explained by the genetic background that influences the inter-population variability of the Mexican population.

VCAM1 polymorphism, was not previously studied in RA patients, and we not find an association in these patients. However, in healthy African Americans was reported a high frequency of the $V C A M 1 \mathrm{G} / \mathrm{C}$ genotype $(27 \%)$ whereas in German Caucasians, they reported a $23 \% \mathrm{G} / \mathrm{C}$ frequency $[14,15]$. In this study, the frequency of VCAM1 G $>\mathrm{C}$ polymorphism was very low [3\% (RA) versus $2 \%$ (HS)].

In summary, our results suggest that the sVCAM-1 and sICAM-1 serum levels reflect the clinical activity status in RA because they are associated with RF, ESR, HAQ-DI and DAS28 indexes independently of ICAMI and VCAMI polymorphism, but the ICAMI 721A allele could be a genetic marker to RA susceptibility in Western of Mexico. 


\section{Acknowledgements}

This work was supported by grant No. J45703-M to JFMV of the National Council of Science and Technology (CONACyT, México-Universidad de Guadalajara).

\section{References}

[1] D.M. Lee and M.E. Weinblatt, Rheumatoid arthritis, Lancet 358 (2001), 903-911.

[2] J.B. Smith and M.K. Haynes, Rheumatoid arthritis-a molecular understanding, Ann Intern Med 136 (2002), 908-922.

[3] J.J. Goronzy and C.M. Weyand, Rheumatoid arthritis, Immunol Rev 204 (2005), 55-73.

[4] G.S. Firestein, Evolving concepts of rheumatoid arthritis, $\mathrm{Na}$ ture 423 (2003), 356-361.

[5] Z. Szekanecz and A.E. Koch, Mechanisms of Disease: angiogenesis in inflammatory diseases, Nature Clinical Practice Rheumatology 3 (2007), 635-643.

[6] C.M. Weyand and J.J. Goronzy, Pathogenesis of rheumatoid arthritis, Med Clin North Am 81 (1997), 29-55.

[7] T. Lebedeva, M.L. Dustin and Y. Sykulev, ICAM-1 costimulates target cells to facilitate antigen presentation, Curr Opin Immunol 17 (2005), 251-258.

[8] A. Meager, Cytokine regulation of cellular adhesion molecule expression in inflammation, Cytokine Growth Factor Rev 10 (1999), 27-39.

[9] R.W. McMurray, Adhesion molecules in autoimmune disease, Semin Arthritis Rheum 25 (1996), 215-233.

[10] P.P. Sfikakis and G.C. Tsokos, Clinical use of the measurement of soluble cell adhesion molecules in patients with autoimmune rheumatic diseases, Clin Diagn Lab Immunol 4 (1997), 241-246.

[11] A. Meager, C. Bird and A. Mire-Sluis, Assays for measuring soluble cellular adhesion molecules and soluble cytokine receptors, J Immunol Methods 191 (1996), 97-112.

[12] J.D. Rioux and A.K. Abbas, Paths to understanding the genetic basis of autoimmune disease, Nature 435 (2005), 584-589.

[13] J. Ermann and C.G. Fathman, Autoimmune diseases: genes, bugs and failed regulation, Nat Immunol 2 (2001), 759-761.

[14] K. Wenzel, M. Ernst, K. Rohde, G. Baumann and A. Speer, DNA polymorphisms in adhesion molecule genes-a new risk factor for early atherosclerosis, Hum Genet 97 (1996), 15-20.

[15] J.G. Taylor, D.C. Tang, S.A. Savage, S.F. Leitman, S.I. Heller, G.R, Serjeant, G.P. Rodgers and S.J.Chanock, Variants in the VCAM1 gene and risk for symptomatic stroke in sickle cell disease, Blood 100 (2002), 4303-4309.

[16] P. Macchioni, L. Boiardi, B. Casali, D. Nicoli, E. Farnetti and C. Salvarani, Intercellular adhesion molecule 1 (ICAM1) gene polymorphisms in Italian patients with rheumatoid arthritis, Clin Exp Rheumatol 18 (2000), 553-558.

[17] A.J. MacGregor, H. Snieder, A.S. Rigby, M. Koskenvuo, J. Kaprio, K. Aho and A.J. Silman, Characterizing the quantitative genetic contribution to rheumatoid arthritis using data from twins, Arthritis Rheum 43 (2000), 30-37.

[18] E.B. Lee, J.Y. Kim, E.H. Kim, J.H. Nam, K.S. Park and Y.W. Song, Intercellular adhesion molecule-1 polymorphisms in Korean patients with rheumatoid arthritis, Tissue Antigens 644 (2004), 473-477.
[19] F.C. Arnett, S.M. Edworthy, D.A. Bloch, D.J. McShane, J.F. Fries, N.S. Cooper, L.A. Healey, S.R. Kaplan, M.H. Liang, H.S. Luthra et al., The American Rheumatism Association 1987 revised criteria for the classification of rheumatoid arthritis, Arthritis Rheum 31 (1988), 315-324.

[20] C. Gorodezky, C. Alaez, M.N. Vazquez-Garcia, G. de la Rosa, E. Infante, S. Balladares, R. Toribio, E. Pérez-Luque and L. Muñoz, The genetic structure of Mexican Mestizos of different locations: tracking back their origins through MHC genes, blood group systems, and microsatellites, Hum Immunol $\mathbf{6 2}$ (2001), 979-991.

[21] M.H. Cardiel, M. Abello-Banfi, R. Ruiz-Mercado and D. Alarcon-Segovia, How to measure health status in rheumatoid arthritis in non-English speaking patients: validation of a Spanish version of the Health Assessment Questionnaire Disability Index (Spanish HAQ-DI), Clin Exp Rheumatol 11 (1993), 117-121.

[22] M.L. Prevoo, M.A. van 't Hof, H.H. Kuper, van M.A. Leeuwen, L.B. van de Putte and P.L. van Riel, Modified disease activity scores that include twenty-eight-joint counts, Development and validation in a prospective longitudinal study of patients with rheumatoid arthritis, Arthritis Rheum 38 (1995), 44-48.

[23] S.A. Miller, D.D. Dykes and H.F. Polesky, A simple salting out procedure for extracting DNA from human nucleated cells, Nucleic Acids Res 16 (1988), 1215.

[24] M.I. Cybulsky, J.W. Fries, A.J. Williams, P. Sultan, R. Eddy, M. Byers, T. Shows, M.A. Gimbrone, Jr. and T. Collins, Gene structure, chromosomal location, and basis for alternative $\mathrm{mR}$ NA splicing of the human VCAM1 gene, Proc Natl Acad Sci USA 88 (1991), 7859-7863.

[25] M.M. Amoli, E. Shelley, D.L. Mattey, C. Garcia-Porrua, W. Thomson, A.H. Hajeer, W.E. Ollier and M.A. Gonzalez-Gay, Lack of association between intercellular adhesion molecule1 gene polymorphisms and giant cell arteritis, J Rheumatol 28 (2001), 1600-1604.

[26] D.K. Vora, C.L. Rosenbloom, A.L. Beaudet et al., Polymorphisms and linkage analysis for ICAMI and the selectin gene cluster, Genomics 21-3 (1994), 473-477.

[27] A.J. Littler, C.D. Buckley, P. Wordsworth, I. Collins, J. Martinson and D.L. Simmons, A distinct profile of six soluble adhesion molecules (ICAM-1, ICAM-3, VCAM-1, E-selectin, Lselectin and P-selectin) in rheumatoid arthritis, Br J Rheumatol 36 (1997), 164-169.

[28] Y. M. El-Miedany, S. Ashour, H. Moustafa, and IHAB Ahmed, Altered levels of soluble adhesion molecules in patients with rheumatoid arthritis complicated by peripheral neuropathy, $J$ Rheumatol 29 (2002), 57-61.

[29] B.J. Bloom, L.C. Miller, L.B. Tucker, J.G. Schaller and P.R. Blier, Soluble adhesion molecules in juvenile rheumatoid arthritis, J Rheumatol 26 (1999), 2044-2048.

[30] P. Dolezalova, P. Telekesova, D. Nemcova and J. Hoza, Soluble adhesion molecules ICAM-1 and E-selectin in juvenile arthritis: clinical and laboratory correlations, Clin Exp Rheumatol 20 (2002), 249-254.

[31] P.A. Klimiuk, S. Sierakowski, R. Latosiewicz, J.P. Cylwik, B. Cylwik, J. Skowronski and J. Chwiecko, Soluble adhesion molecules (ICAM-1, VCAM-1, and E-selectin) and vascular endothelial growth factor (VEGF) in patients with distinct variants of rheumatoid synovitis, Ann Rheum Dis 61 (2002), 804-809.

[32] C.Y. Chen, C.H. Tsao, L.S. Ou, M.H. Yang, M.L. Kuo and J.L. Huang, Comparison of soluble adhesion molecules in juvenile 
idiopathic arthritis between the active and remission stages, Ann Rheum Dis 61 (2002), 167-170.

[33] K. Degitz, L. Lian-Jie and S. Wright Caughman, Cloning and characterization of the 5'-transcriptional regulatory region of the human intercellular adhesion molecule 1 gene, The J Biol Chem 266-21 (1991), 14024-14030.

[34] D.H. Verity, R.W. Vaughan, E. Kondeatis, W. Madanat, H. Zureikat, F. Fayyad, J.E. Marr, C.A. Kanawati, G.R. Wallace and M.R. Stanford, Intercellular adhesion molecule-1 gene polymorphisms in Behcet's disease, Eur J Immunogenet 27 (2000), 73-76

[35] P. Vigano, M. Infantino, D. Lattuada, R. Lauletta, E. Ponti, E. Somigliana, M. Vignali and A.M. DiBlasio, Intercellular adhesion molecule-1 (ICAMI) gene polymorphisms in endometriosis, Mol Hum Reprod 9 (2003), 47-52.

[36] M. Yamashita, S. Yoshida, S. Kennedy, N. Ohara, S. Motoyama and T. Maruo, Association study of endometriosis and intercellular adhesion molecule-1 (ICAM1) gene polymorphisms in a Japanese population, J Soc Gynecol Investig 12 (2005), 267-271.

[37] A. Ponthieux, D. Lambert, B. Herbeth, S. Droesch, M. Pfister and S. Visvikis, Association between Gly241Arg ICAMI gene polymorphism and serum sICAM-1 concentration in the Stanislas cohort, Eur J Hum Genet 11 (2003), 679-686.

[38] S. Borozdenkova, J. Smith, S. Marshall, M. Yacoub and M. Rose, Identification of ICAM1 polymorphism that is associated with protection from transplant associated vasculopathy after cardiac transplantation, Hum Immunol 62 (2001), 247-255.

[39] A. Kretowski, N. Wawrusiewicz, K. Mironczuk, J. Mysliwiec, M. Kretowska and I. Kinalska, Intercellular adhesion molecule 1 gene polymorphisms in Graves' disease, J Clin Endocrinol Metab 88 (2003), 4945-4949.

[40] C. Salvarani, B. Casali, L. Boiardi, A. Ranzi, P. Macchioni, D. Nicoli, E. Farnetti, M. Brini and I. Portioli, Intercellular adhesion molecule 1 gene polymorphisms in polymyalgia rheumatica/giant cell arteritis: association with disease risk and severity, J Rheumatol 27 (2000), 1215-1221.

[41] A.J. McLaren, S.E. Marshall, N.A. Haldar, C.G. Mullighan, S.V. Fuggle, P.J. Morris and K.I. Welsh, Adhesion molecule polymorphisms in chronic renal allograft failure, Kidney Int 55 (1999), 1977-1982.

[42] Y.K. Kim, C.W. Pyo, S.S. Hur, T.Y. Kim and T.G. Kim, No associations of CTLA-4 and ICAM1 polymorphisms with psoriasis in the Korean population, J Dermatol Sci 33 (2003), 75-77.
[43] M.M. Amoli, W.E. Ollier, M. Lueiro, M.L. Fernandez, C. Garcia-Porrua and M.A. Gonzalez-Gay, Lack of association between ICAM-1 gene polymorphisms and biopsy-proven erythema nodosum, J Rheumatol 31 (2004), 403-405.

[44] M.W. Quasney, G.W. Waterer, M.K. Dahmer, D. Turner, Q. Zhang, R.M. Cantor and R.G. Wunderink, Intracellular adhesion molecule Gly241Arg polymorphism has no impact on ARDS or septic shock in community-acquired pneumonia, Chest 121 (2002), 85S-86S.

[45] X. Yang, S.N. Cullen, J.H. Li, R.W. Chapman and D.P. Jewell, Susceptibility to primary sclerosing cholangitis is associated with polymorphisms of intercellular adhesion molecule- $1, J$ Hepatol 40 (2004), 375-379.

[46] M.M. Amoli, E. Shelley, D.L. Mattey, C. Garcia-Porrua, W. Thomson, A.H. Hajeer, W.E. Ollier and M.A. Gonzalez-Gay, Intercellular adhesion molecule-1 gene polymorphisms in isolated polymyalgia rheumatica, J Rheumatol 29 (2002), 502 504.

[47] E.G. Corona-Sanchez, L. Gonzalez-Lopez, J.F. Muñoz-Valle, M. Vazquez-Del Mercado, M.A. Lopez-Olivo, E.A. AguilarChavez, M. Salazar-Paramo, C. Loaiza-Cardenas, E. OregonRomero, R.E. Navarro-Hernandez and J.I. Gamez-Nava, Circulating E-selectin and tumor necrosis factor-alpha in extraarticular involvement and joint disease activity in rheumatoid arthritis, Rheumatol Int 29(3) (2009), 281-286.

[48] D. Elewaut, F. De Keyser, N. De Wever, D. Baeten, N. Van Damme, G. Verbruggen, C. Cuvelier and E.M. Veys, A comparative phenotypical analysis of rheumatoid nodules and rheumatoid synovium with special reference to adhesion molecules and activation markers, Ann Rheum Dis 57 (1998), 480-486.

[49] J.C.W. Edwards, L.S. Wilkinson and A.A. Pitsillides, Palisading cells of rheumatoid nodules: comparison with synovial intimal cells, Annals of the Rheumatic Diseases 52 (1993), 801-805.

[50] V. García-Patos, Semin Cutan Med Surg 26(2) (2007), 100107.

[51] C. Turesson and E.L. Matteson, Vasculitis in rheumatoid arthritis, Current Op in Rheum 21 (2009), 35-40.

[52] I. Ghersetich and T. Lotti, Cellular steps in the pathogenesis of cutaneous necrotizing vasculitis, Int Angiol 14(2) (1995), $107-112$

[53] J.R. Bradley, C.M. Lockwood and S. Thiru, Endothelial cell activation in patients with systemic vasculitis, QJM 87(12) (1994), 741-745. 


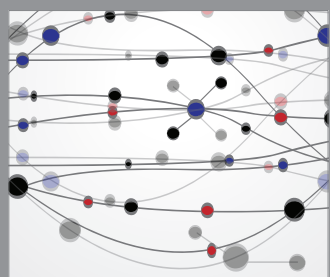

The Scientific World Journal
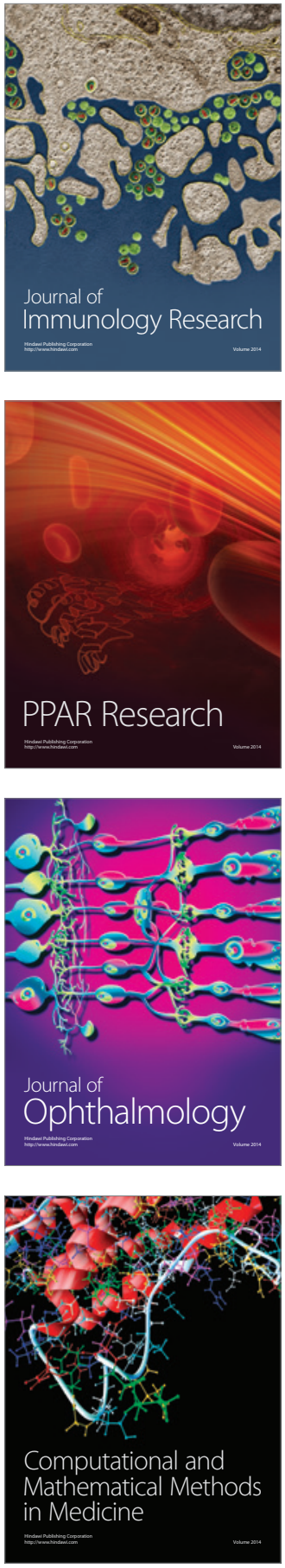

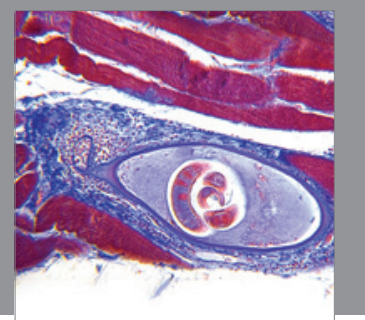

Gastroenterology

Research and Practice
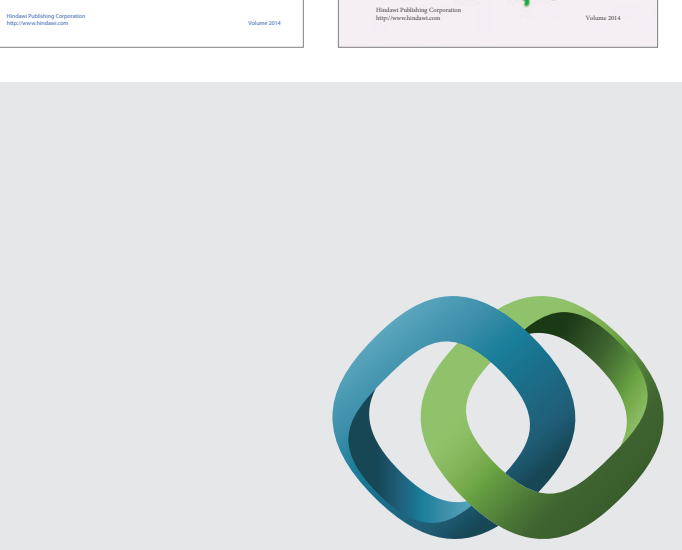

\section{Hindawi}

Submit your manuscripts at

http://www.hindawi.com
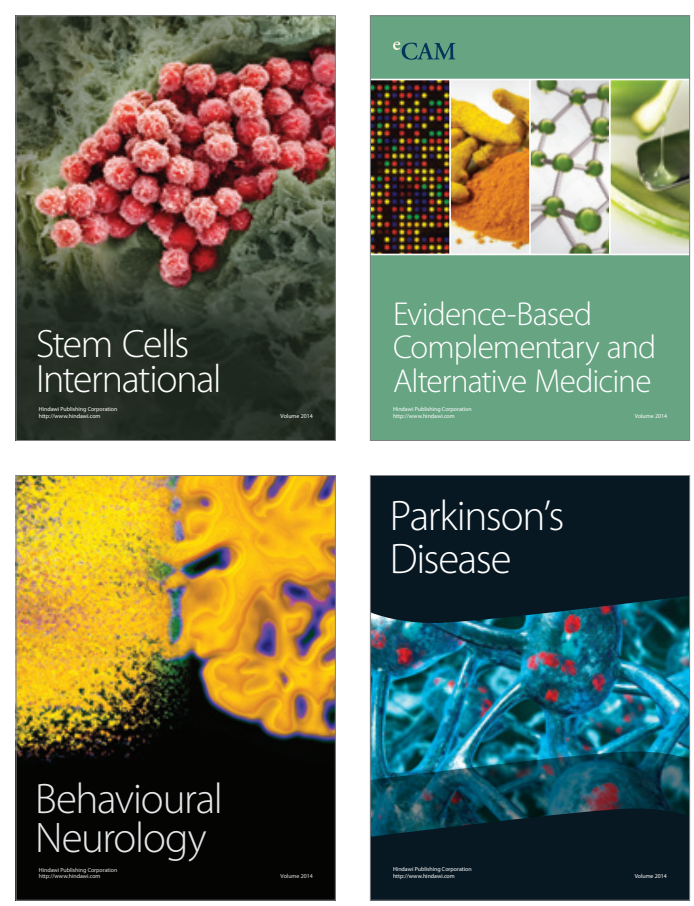

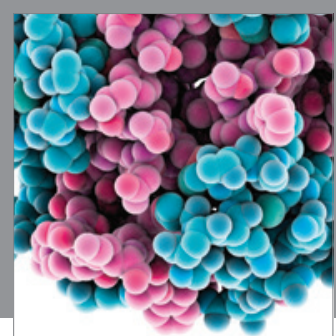

Journal of
Diabetes Research

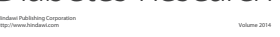

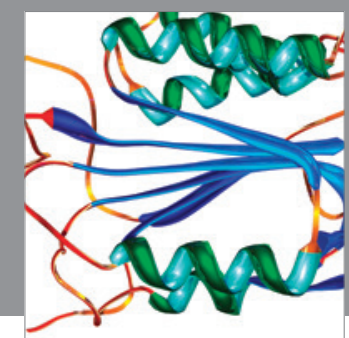

Disease Markers
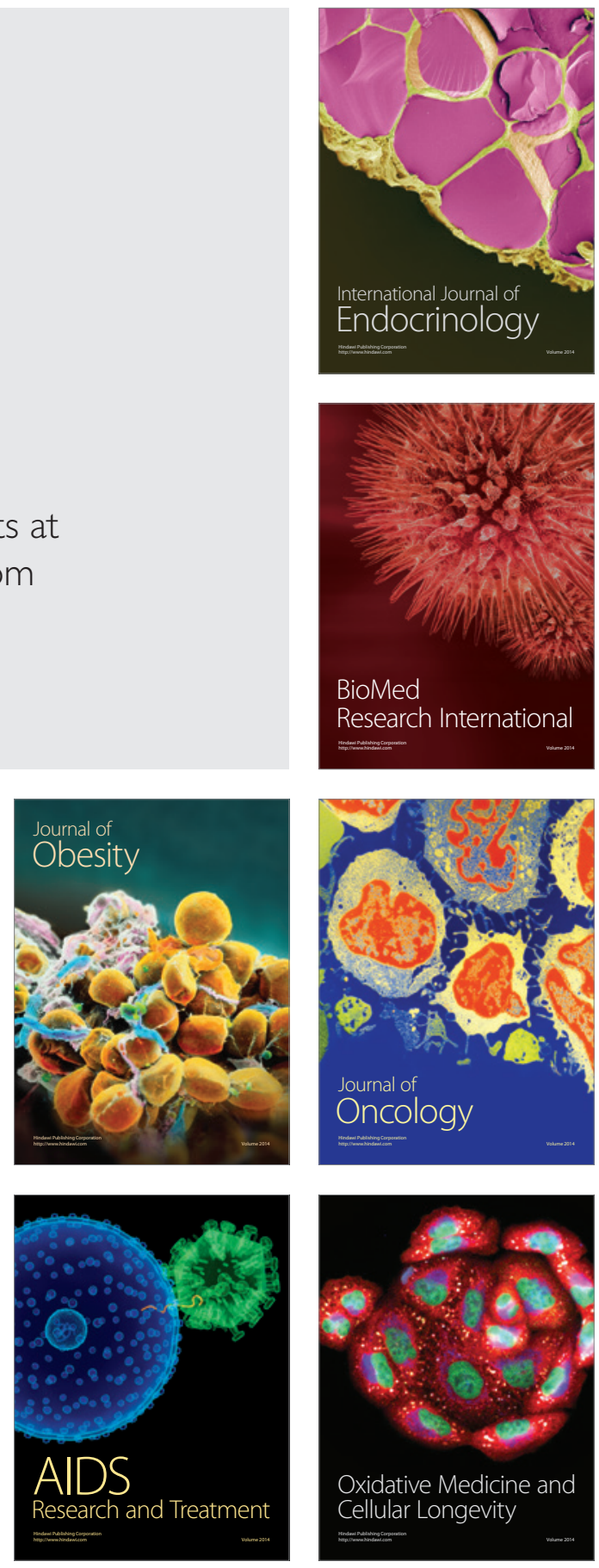